Corporate Social Responsibility and Corporate Identity: Potentials for Disciplinary Cross-Fertilization within Research and Teaching

Anne Ellerup Nielsen, PhD, Associate Professor, Centre for Corporate Communication, Aarhus School of Business, University of Aarhus

Trine Susanne Johansen, MA, PhD Student, Centre for Corporate Communication, Aarhus School of Business, University of Aarhus

Anne Ellerup Nielsen: aen@ asb.dk

Trine Susanne Johansen: $\underline{\text { tsj@asb.dk }}$ 


\title{
Corporate Social Responsibility and Corporate Identity: Potentials for Disciplinary Cross-Fertilization within Research and Teaching
}

\begin{abstract}
Through a review of CSR and corporate identity literature placed within a stakeholder perspective, the paper addresses potential cross-fertilization between CSR and corporate identity research focusing on fostering stakeholder dialogue when addressing corporate accountability and legitimacy. The stakeholder perspective acts as a framework for a crossdisciplinary approach proposing that different stakes (i.e. those of employees, shareholders, consumers etc.) condition different dialogue forms and scripts evoking similar aspects of corporate identity and CSR in different ways. The findings call for further research into the cross-disciplinary potentials of the proposed model.
\end{abstract}

Key words - Corporate identity, corporate social responsibility, stakeholders, crossdisciplinary research

\section{Introduction}

Societal developments and increasing stakeholder awareness have placed accountability and responsibility on corporate agendas emphasizing the ability of companies to secure their licenses to operate. As companies have to act in new ways in order to deal with pressures brought on by a number of different issues (climate change, sustainability, financial scandals and crisis etc.), corporate social responsibility (CSR) has begun to inform other disciplines such as corporate strategy (Lamberti and Lettieri, 2009), corporate marketing (Podnar and Golob, 2007) and corporate communication (Cornelissen, 2008; van Riel and Fombrun, 2007). Legitimacy and corporate citizenship have accordingly attained a more central position within recent research on corporate identity (Balmer et al. 2007; Roland and Bazzoni, 2009) as studies have shown that CSR has become a key driver when measuring corporate reputation (Morsing et al., 2008). Simultaneously, European companies have experienced a move away from state and governmental regulation towards a higher degree of self-regulation and delegation of responsibility to organizations themselves (European Commission, 2001). The move towards greater self-regulation has meant a shift in relation to how companies 
communicate CSR activities from implicit to more explicit forms of communication.

Consequently, as CSR is considered to be of increasing importance, it may be argued that it is also becoming an aspect of corporate identity management and communication (Balmer et al., 2007; Nielsen and Thomsen, 2009). Although the challenges posed by societal developments and stakeholder awareness are similar when viewed from CSR and corporate identity perspectives, little research has been carried out on potential cross-fertilization.

The paper argues that potential overlaps in the stakeholder orientations of CSR and corporate identity research can aid in handling societal challenges by strengthening communication as a dialogical tool in relationship building. Dialogue is introduced as a key aspect in CSR, corporate identity and stakeholder research, but the question remains how dialogue can be initiated or scripted? We seek to provide a provisional answer by beginning with a brief outline of the stakeholder perspective which frames our approach. Secondly, we tentatively identify how different stakeholders, and the varying stakes they hold, are addressed within the two research disciplines. Finally, based on such identification and the similarities between the two, we discuss how to foster stakeholder dialogue through dialogue forms and the implementation of dialogue scripts based on different stakes and interests held by stakeholders.

\section{The stakeholder approach}

The stakeholder approach to understanding organizations in their environments has paved the way for a broader perception of organizational roles and responsibilities beyond profit maximization as compared to the traditional shareholder perspective. An organization is defined in terms of a grouping of stakeholders. Its mission is hence not only to provide benefits for shareholders and owners but rather to integrate interests and claims from other groups into the strategic management of the business (Mitchell et al., 1997, p.853; Friedman and Miles, 2006, p.1). Since the mid-1980s, the stakeholder concept has grown in popularity not only in academic circles but also among policymakers, regulators, NGOs, businesses and the media. However, the concept is not clearly defined. It is multiple and fluid covering a broad spectrum of interests, meanings and schools of thought ranging from political economy to institutional and management theory. Philosophically speaking, stakeholding represents a general sense of social inclusion in a community in which every citizen is a valued member who contributes and benefits. From a participatory perspective, stakeholding assumes active 
participation in processes of accountability; and financially speaking a material interest in the well-being of an enterprise is what legitimates such participation (Clarke, 1997, p.211).

Robert E. Freeman, one of the fathers of stakeholder theory, defines stakeholders as "groups and individuals who can affect, or are affected by the achievement of an organization's mission" (Freeman, 1984:52). Typical stakeholders include customers, non-governmental organizations, employees, unions, competitors, suppliers, governments and investors.

Stakeholder management refers to the necessity of an organization to manage its relationship with stakeholders on an action-oriented basis (Freeman, 2005, p.122). However, since Freeman's introduction of stakeholder theory in 1984, a postmodern approach has replaced the idea of 'stakeholder management' with that of 'stakeholder enabling' indicating a shift from a static, instrumental perception of stakeholders who can be 'managed' towards a notion of stakeholders as groups involved in dynamic interaction with post-bureaucratic, networked organizations (Calton and Kurland, 1995; Friedman and Miles, 2006).

Legitimacy and accountability are crucial to the stakeholder perspective. Stakeholders expect companies to earn their licenses to operate by paying back to society some of their benefits and by taking on responsibility for solving societal problems. As legitimacy becomes increasingly salient, CSR issues such as employee end environmental policies also speak to the identity of a corporation. The stakeholder approach implies that different stakeholders, once identified, must be addressed in relation to the stake(s) they hold and that communication must be adjusted to these stake(s) as they determine stakeholder interest in certain aspects of the company (Cornelissen, 2008, p.49) including its CSR activities and corporate identity.

\section{Stakeholders within CSR and corporate identity}

\section{Corporate Social Responsibility}

Generally, CSR is about businesses' good deeds in society. CSR embraces issues ranging from legal compliance, philanthropy and community investment to environmental management, sustainability, animal rights, human rights, workers' rights and welfare, market relations, corruption and corporate governance (Blowfield and Murray, 2008). However, there is no general consensus on CSR. Within a European framework, CSR is defined as corporate social initiatives that are voluntary and beyond regulation. It is framed in relation to both 
internal and external subareas of responsibility such as recruitment and retention, health and security on the working place, change management, working environment, stakeholders in local communities plus suppliers, customers and others, human rights and global environmental considerations (cf. EU Commission, 2001). Following the EU agenda, it is clear that CSR cannot be isolated from the stakeholder perspective as supported by many CSR researchers (e.g. Wood, 1991; Papasolomouet et al., 2005; Jamali, 2008).

Since stakeholder dialogue is the issue in this paper, we find it relevant to give a brief account of CSR communication. From a public policy perspective, CSR communication is considered a question of businesses' capacity to respond to social pressure rather than only an obligation to work for social betterment (Valentin, 2006). In this sense, CSR is conceptualized as corporate social responsiveness (Frederick, 1978). Introducing a notion of responsiveness places stakeholder dialogue in a central position. If managers are required to adapt their businesses to the social environment by practicing corporate policies that are responsive to the public (Valentin, 2006), they may be expected to enter into dialogue with stakeholders.

Within communication research, a transmission understanding of communication is overruled by more interactive approaches focusing on establishing and maintaining good relationships through dialogue. Inspired by Grunig and Hunt's model of public relations (Grunig \& Hunt, 1984), Morsing and Schultz (2006) establish a framework of CSR communication arguing that stakeholders can be approached using various communication strategies that take into account the contextual and dynamic features of specific communicative frames. The stakeholder information strategy (one-way communication) is used when organizations want to transmit factual information about their business to stakeholders with the aim of informing as objectively as possible about organizational issues (Morsing and Schultz, 2006, p.142). The stakeholder response strategy (two- way asymmetrical communication) is used when organizations try to engage stakeholders in actions and decision-making with the aim of obtaining external endorsement through market surveys, opinion polls and the like (Ibid. p. 143). The stakeholder involvement strategy (two-way symmetrical communication) is used to achieve dialogue with stakeholders. The idea behind this strategy is that organizations should not only try to influence their stakeholders, they should also learn from them by taking in their advice and putting it into practice "in order to explore mutually beneficial action assuming that both parties involved in the dialogue are willing to change" (Ibid., p.145). While the information and response strategies are sender-oriented and views stakeholders as passive receivers, the involvement strategy invites stakeholders to participate. However, 
stakeholder involvement in CSR issues differ based on the nature of the stakes held by specific stakeholder groups.

The role of NGOs is to protect society from corporations doing harm. Their interest in engaging in dialogue with corporations ranges from influencing business practice, representing their organization and members' interests, retaining legitimacy and operability, gaining a better understanding of the different sides of the debate to achieving outcomes that can only be reached by working in partnerships with private corporations (Burchell and Cook, 2008, p. 39). However, NGOs also fear that their engagement with businesses will be giving legitimacy to the business agenda of CSR and to endorse their products (ibid.). Consumers' interest in CSR is that they need socially committed organizations in support of their own consumption pattern. This mechanism is based on of how consumers can legitimize their own identity as socially conscious consumers (Taifel and Turner, 1986). Through brand preference, choice and consumption, consumers create meaning and try to define or strengthen their identity as socially responsible consumers (Belk, 1988; McCracken, 1986; Andersen \& Nielsen, forthcoming). Investors' stake is related to risk minimization. The stock market's reaction to bad management and corporate governance practices following business crises and scandals can often be risky business for investors, of which the Enron scandal has become the business case (e.g. Maak, 2008). Suppliers have to live up to their customers' claims in order to keep their business profits. Consequently, they have to present themselves as attractive and innovative actors in the market by taking over corporate branding, strategic communication and reputation instruments from large corporations (Morsing, Vallentin and Hildebrandt, 2008). Employees have an interest in keeping their job, but what is more and more important, in keeping a safe and healthy working environment that allows them to develop and construct their identity and express themselves in a meaningful way through their work. It is also of great importance that employees have a close and relevant relationship to their organizations in order to act as good ambassadors in the environment (Christensen, Morsing \& Cheney, 2008. P. 72.). The different interests of the stakeholders call for adapted communication forms and scripts.

\section{Corporate Identity}

Corporate identity can be defined in multiple ways (see e.g. Cornelissen and Harris 2001; Alessandri, 2001; Balmer, 2008). However, in this paper it is understood as "the way in which 
an organization's identity is revealed through behaviour, communications, as well as through symbolism to internal and external audiences" (van Riel and Balmer, 1997. p. 341). Defined as a company's self-presentation, corporate identity is ascribed a boundary-spanning role between the company and its surroundings - creating and maintaining relationships with numerous stakeholders groups e.g. consumers, customers, investors, employees, suppliers, NGOs, the media and the general public (Cornelissen, 2004). As such it is regarded as an important strategic resource in relation to ensuring that a company is perceived as credible by its stakeholders (Melewar, 2003, p. 195)

Generally, corporate identity is said to foster positive reputations and favourable stakeholder relations. However, the potential benefits attributed to corporate identity in relation to creating and maintaining stakeholder relations are often specified according to the specific nature of the stake that a particular stakeholder or group of stakeholders has in a company (Melewar et al., 2005). Investors and shareholders are interested in information relating to strategy and operations (Cornelissen 2008, p.49) as the stake they hold is financial. Customers favour identity elements related to the distinctiveness, quality and desirability of products and services (ibid.) often expressed in brand promises. Suppliers are more likely to stay loyal and have confidence in the company (van Riel 1995, p.29). Employees are said to become motivated and satisfied with their jobs as they come to understand the purpose, direction and focus of their company (Melewar 2003, p.195). In addition, corporate identity can create identification by promoting a 'we-feeling' amongst employees leading to higher loyalty and commitment (van Riel, 1995, p. 29). Consequently, a company is faced with many different, perhaps conflicting, aspects of its identity when addressing each stakeholder group.

Addressing different stakeholders may require the organization to speak with multiple voices i.e. to employ polyphonic communication (Christensen et al., 2008) said to allow corporate mobility and flexibility in self-presentation embracing societal complexities and varying stakeholder interests (ibid.).

Corporate identity thus plays different roles in different stakeholder relations reflecting the different stakes held. These differences also become manifest in polyphonic communication as companies are encouraged to enter into dialogue with multiple stakeholder groups based on the nature of their specific stakes. However, within existing literature little emphasis is given as to how such dialogue is to be established and maintained. Below we suggest that successful stakeholder dialogue is determined by a company's ability to address specific stakeholder 
interests when communicating both CSR and identity and suggest that these different interests be explored through dialogue forms and accompanying dialogue scripts.

\section{Stakeholder dialogue within CSR and corporate identity: from strategy to scripts}

Having outlined key aspects of CSR and corporate identity with reference to the stakeholder perspective, the two disciplines inform a framework for designing dialogue forms and scripts allowing for the identity and CSR communication to be targeted at specific stakeholders. The intention is not to suggest integrating one into the other as e.g. ethical identity; a notion discussed and rejected by Balmer et al., 2007, but rather that similar solutions might be sought when seeking to encourage stakeholder dialogue. As addressed earlier, dialogue is a key aspect within corporate identity research and CSR where it (in relation to stakeholder involvement) is addressed as an important strategy within CSR communication (Morsing and Schultz, 2006). We propose to develop this strategy by using specific stakes to sketch out dialogue forms and scripts in relation to select stakeholders as an important step in exploring and explicating an approach for stakeholder dialogue. Form refers to the type of interaction embedded in the dialogue whereas script refers to a set of discursive conventions and rules implied in a specific form.

\begin{tabular}{|l|l|l|l|}
\hline Stakeholders & Stake/interest & Dialogue form & Dialogue script \\
\hline Consumers & $\begin{array}{l}\text { Seek quality, licence to consume } \\
\text { and distinctiveness }\end{array}$ & Networking & $\begin{array}{l}\text { Experience and } \\
\text { engagement }\end{array}$ \\
\hline Investors & $\begin{array}{l}\text { Seek pay-off, risk minimization } \\
\text { and responsible investment }\end{array}$ & Briefing & $\begin{array}{l}\text { Ensuring and balancing } \\
\text { (finance and ethics) }\end{array}$ \\
\hline Employees & $\begin{array}{l}\text { Seek identification, safety and job } \\
\text { satisfaction }\end{array}$ & Involvement & $\begin{array}{l}\text { Sense-making and } \\
\text { cultural enactment }\end{array}$ \\
\hline NGOs & $\begin{array}{l}\text { Seek influence, control, } \\
\text { awareness and legitimacy }\end{array}$ & Negotiation & $\begin{array}{l}\text { Compromising and } \\
\text { partnering }\end{array}$ \\
\hline Suppliers & $\begin{array}{l}\text { Seek commitment, long-lasting } \\
\text { relationships and inclusion }\end{array}$ & Exchange & $\begin{array}{l}\text { Knowledge-sharing and } \\
\text { (mutual) learning }\end{array}$ \\
\hline
\end{tabular}

The framework suggests that since stakeholders belong to diverse interest communities, companies ought to address these differences not only from a strategic perspective but also in relation to the communicative forms and scripts applied when entering into dialogue with the 
individual stakeholder groups. Furthermore, it could be implied that the individual stakes should condition the nature and features of the dialogue. In other words, companies should be more aware of discursive practices and conventions within stakeholder groups.

\section{Conclusive remarks}

The conclusions drawn from the provisional overview into potentials for cross-fertilization between CSR and corporate identity indicate that interesting parallels exist between the two disciplines. Moreover, such parallels may be utilized in developing a framework for fostering successful stakeholder dialogue. However, additional research into the cross-disciplinary potentials is needed in order to develop a complete and elaborate framework with relevance for research, teaching and practice.

\section{Bibliography}

Alessandri, S.W. (2001), "Modeling corporate identity: a concept explication and theoretical explication”, Corporate Communications: An International Journal, Vol. 61, No. 4, pp. 173-182

Balmer, J.M.T. (2008), "Identity based views of the corporation: Insights from corporate identity, organizational identity, social identity, visual identity, corporate brand identity and corporate image", European Journal of Marketing, Vol. 42. No. 9/10, pp. 879-906

Balmer, J.M.T., Fukukaw, K. and Gray, E. R. (2007), “The Nature and Management of Ethical Corporate Identity: A Commentary on Corporate Identity, Corporate Social Responsibility and Ethics”, Journal of Business Ethics, Vol.76, No. 7, pp. 7-15

Belk, R. W. (1988), "Posessession and Extended Self”, Journal of consumer research, Vol. 15 , pp. $130-168$

Blowfield, M and Murray, A. (2008), Corporate Responsibility: A Critical Introduction, Oxford University Press, USA

Calton, J.M., Kurland, N.B. (1995), "A theory of stakeholder enabling: giving voice to an emerging postmodern praxis of organizational discourse", in Boje, D.M., Gephart, R.P., Thatchenkery, T.J. (Eds),Postmodern Management and Organization Theory, Sage, London, pp.154-77

Christensen, L.T; Morsing, M. and Cheney, G. (2008), Corporate Communications. Convention, Complexity, and Critique, Sage Publications, London 
Clarke, T. (1997): "Measuring and managing stakeholder relations", Journal of Communication Management, vol. 2. No. 3, 211-221.

Cornelissen, J.(2008). Corporate Communication: A guide to theory and practice. Sage Publications, London

Cornelissen, J. and Harris, P. (2001), “The Corporate Identity Metaphor: Perspectives, Problems and Prospects", Journal of Marketing Management, Vol. 17, pp.59-71 European Commission (2001). Promoting a European framework for corporate social responsibility. Green Paper. European Commission, Bruxelles.

Frederick, W. C. (1978), Corporation Be Good! The Story Of Corporate Social Responsibility, Indiana: Dog Year Publishing

Freeman, R.E. (1984), Strategic Management: A Stakeholder Approach, Pitman, Boston, MA Freeman, R. E. (2005), “Stakeholder Management: Framework and Philosophy”, in, P. S. Brønn \& R. W. Berg (eds.), Corporate Communication - A Strategic Approach to Building Reputation, $2^{\text {nd }}$. Ed. pp. 121-148

Friedman, A.L. and Miles, S. (2006), Stakeholders. Theory and Practice, Oxford University Press, New York

Grunig, J.E. and Hunt, T. (1984), Managing Public Relations, Hartcourt Brace Javanovich College Publishers, Fort Worth

Jamali, D. (2008) "Social Responsibility: A Fresh Perspectiveinto Theory and Practice", Journal of Business Ethics, vol. 82, pp. 213-31

Lamberti, L. and Lettieri, M. (2009), “CSR Practices and Corporate Strategy: Evidence from a Longitudinal Case Study”, Journal of Business Ethics, Vol. 87, No. 2, pp. 153-168

Maak, T. (2008),’Undivided Corporate Responsibility:Towards a Theory of Corporate Integri”, Journal of Business Ethics, Vol. 82, pp. 353-368

Matten, D. and Moon, J. (2008),"“'Implicit" and "explicit" CSR: A conceptual framework for a comparative understanding of corporate social responsibility", The Academy of Management Review, Vol. 33. No. 2, pp. 404-424

McCracken, G. (1986), "Culture and consumption”, Journal of Consumer Research, Vol. 13 , pp.71-84

Melewar, T.C. (2003), "Determinants of the corporate identity construct: an overview of the literature", Journal of Marketing Communications, 9, pp. 195-220 
Melewar, T.C., Karaosmanoglu, E. and Paterson, D. (2005), “Corporate identity: concept, components and contribution", Journal of General Management, Vol. 31, No. 1, pp. 5981

Mitchell, R.K., Agle, B. and Wood, D. (1997), "Toward a theory of stakeholder identification and salience: defining the principle of who and what really counts", Academy of Management Review, Vol. 22, No.4, pp. 853-886

Morsing, M. and Schultz, M. (2006), "Stakeholder Communication Strategies" in, Morsing, M. and Beckman, S.C. (eds.), Strategic CSR Communication, DJØF Publishing, Copenhagen, pp. 135-160

Morsing, M., Schultz, M. and Nielsen, K. (2008), “The 'Catch 22' of communicating CSR: Findings from a Danish study”, Journal of Marketing Communications. Vol. 14, No. 2, pp. $97-111$

Morsing, Mette og Vallentin, Steen og Hildebrandt, Sten (red.) (2008): Social ansvarlighed: forretning eller ansvar? København: Børsens Forlag.

Nielsen, A.E. and Thomsen, C. (2009), "Investigating CSR communication in SMEs: a case study among Danish middle managers", Business Ethics: A European Review, Vol. 18, No.1, pp.83-93

Papasolomou-Doukakis, I., M. Krambia-Kapardis and M.Katsioloudes (2005), “Corporate Social Responsibility: The Way Forward? Maybe Not!”, European Business Review, Vol. 17, No., 3, pp. 263-279

Podnar, K. and Golob, U. (2007), "CSR expectations: the focus of corporate marketing", Corporate Communications: An International Journal, Vol. 12, No. 4, pp. 326-340

Roland, D \& Bazzoni J.O. (2009),"Greening corporate identity: CSR online corporate identity reporting”, Corporate Communications: An International Journal, Vol. 14, No 3, pp. 249-263

Tajfel, H. \& Turner, J. C. (1986), “The social identity theory of inter-group behavior”. In S. Worchel \& L. W. Austin (Eds.), Psychology of Intergroup Relations. Chigago: NelsonHall

Vanletin, S., (2006), “Corporate social responsiveness and public opinion”, in, Morsing, M. and Beckman, S.C. (eds.), Strategic CSR Communication, DJØF Publishing, Copenhagen, pp. 61-82

van Riel, C.B.M. (1995), Principles of Corporate Communication, Prentice Hall, Harlow 
van Riel, C.B.M and Balmer, J.M.T. (1997), "Corporate identity; the concept, its measurement and management, European Journal of Marketing, Vol. 31, No. 5/6, pp. 340-355

van Riel, C.B.M. and Fombrun, C.J. (2007), Essentials of corporate communication. Implementing practices for effective reputation management, Routledge, London

Wood, D.: (1991), 'Corporate Social Performance Revisited', The Academy of Management Review, Vol. 16, No. 4, pp. 691-717 